\title{
精密滤過用多孔質膜の製法と特徵
}

\author{
平田 繁・松本幹治・大矢晴彦
}

横浜国立大学工学部物質工学科 化学プロセス工学大講座 齿 240 横浜市保土ヶ谷区常盤台 156

\section{Preparation Methods and Characteristics of Porous Membranes for Microfiltration}

\section{Shigeru Hirata, Kanji Matsumoto and Haruhiko Ohya}

\author{
Department of Material Science \& Chemical Engineering, Yokohama National \\ University, Hodogayaku, Yokohama 240
}

Cut-off properties of porous membranes for microfiltration depend upon the pore-size distribution of those membranes, because the suspended particles are rejected by the porous membranes based on the size difference between the particle and the membrane pores. Therefore the control of pore size distribution during the membrane preparation is important to achieve a high reliability of the microfiltration processes. In this review, we summarized the conventional preparation methods of three kinds of porous membranes, that is, polymeric, ceramic and metallic membranes, and pointed out that the ceramic membrane has a bright prospect of developing the new industrial fields of microfiltration, although the efficient preparation method of this membrane to supply inexpensively has not been developed yet.

Key words : Microfiltration, Filtration, Porous membrane, Preparation, Suspension, Particle

\section{1.はじめに}

精密濾過法は, $0.01 \mu \mathrm{m}(10 \mathrm{~nm})$ から $10 \mu \mathrm{m}$ 程度 の微細孔を無数に有する多孔質膜によって液体中に馝濁 した微粒子やコロイド, 菌体などを捕捉・分離する単位 操作である. 水中に分散した油滴（エマルジョン）等も 全く同じ様に分離できることが知られている ${ }^{1)}$. 半導体 工業において問題となるサブサブミクロンオーダーの粒 子や水中ウイルスのように極めて小さい懸濁粒子は, 多 孔質膜と粒子の各表面荷電による電気的吸着作用を利用 して捕捉・分離することも可能であるが ${ }^{2)}$, 通常は䋅濁 粒子と膜細孔の大きさの違いによって粒子の分離がなさ れる. したがって, 精密滤過の分離精度は多孔質膜の細 孔径分布に依存するところが大きく, それを適度に制御
できる様な優れた製膜法が長い間求められてきた. また， ある程度の分離精度が達成されると, 続いて優れた耐熱 性や耐薬品・溶剂性, 機械的強度, モジュール加工性等 が要求される様になり, 異なる製法や素材による膨大な 種類の多孔質膜が開発・商品化されるに至った。

そこで現在, 精密濾過用に市販, あるいは開発提供さ れている有機高分子膜, セラミック膜, 金属膜について, その主な製法の種類と特徴を整理してみたい.

\section{2. 有機高分子膜}

\section{1 相転換法}

有機溶剤に有機高分子を溶解させて調製した製膜溶液 (キャスト液) をガラス板などに流延（キャスト）した 


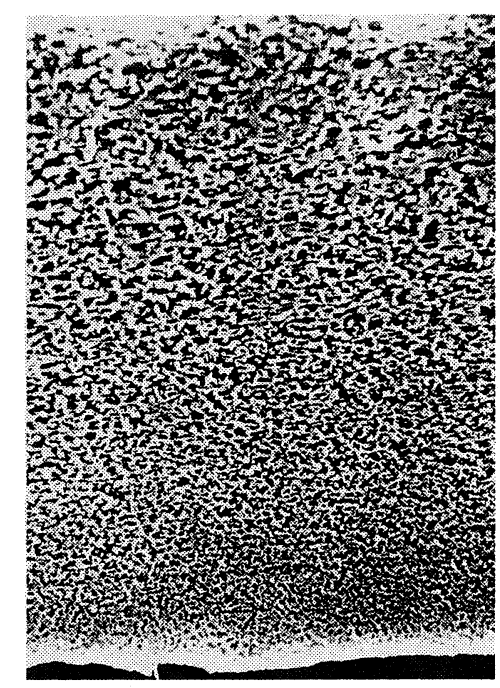

Fig. 1 相転換法で製膜された酶酸セルロース膜の SEM 写真

(FM 45 膜，富士写真フィルム(株)製)

後，それを適当なゲル化液（有機高分子の不溶な有機溶 剤，水など）に浸し，その際に生じる 2 相分離現象を利 用して微細孔を形成させる方法であり ${ }^{3)}$, 有機高分子膜 の製法として最も一般的に用いられている方法である. すでにセルロース系 ${ }^{4 \cdot 5)}$ ，ポリスルホン ${ }^{6) ， ホ^{1} リ カ ー ホ ゙ ~}$ ネート ${ }^{7)}$ ポリビニルアルコール ${ }^{8)}$ などを素材とした膜 がこの方法で作られており, 膜に形成される細孔の径と 分布は, キャスト溶液中に含まれる有機溶剂の種類 ${ }^{9}$ や 高分子の添加量 ${ }^{10)}$, 高分子のブレンド比 ${ }^{10)}$, ゲル化時 間や温度 ${ }^{11}$ などによって調節することができる，最近 では，相転換法によって得た膜を焼成 (annealing) さ せたり ${ }^{12.13)}$ ，あらかじめキャスト溶液中に添加してお いた $\mathrm{LiCl}$ を相転換後に溶出させたりする方法 ${ }^{14)} に$ よって開孔率の高い膜を得ることも試みられている.

なお，相転換を行なう方法としては，上記のように， ゲル化浴を用いる方法の他に, キャスト操作後, 自然乾 燥, あるいは飽和蒸気中で乾燥する方法 ${ }^{15)}$ などもあり, これらの製法はセルロース系16１7)，ポリアミド18), テフロン ${ }^{19)}$ などを素材とした製膜に利用されている.

相転換法によって製膜された多孔質膜の 1 例を Fig. 1 に示す. 相転換法では, Fig. 1 に示したように, 膜の 表と裏の緻密さが異なる，いわゆる “非対称膜”之呼ば れる構造の膜が得られる. 一般に, 多孔質膜の粒子分画 性能は, その膜の最も緻密な層における細孔径とその分 布に依存するが, Fig. 1 から推察されるように, 細孔の
膜 (MEMBRANE), No. 18 Vol. 5 (1993) 265

粗い膜面側から濾過を行なえば，大部分の粒子は，その 裏側の緻密層に到達するまでの間に捕捉されてしまい, 膜の見掛けの分画性能は, 細孔の緻密な膜面側から濾過 を行った場合よりも高くなる，すなわち，細孔の粗い膜 面側から滤過を行えば, 要求される分離精度に対して, より大きな細孔を有する膜を選択できるわけであり, 結 果的に高い濾過速度を得ることが可能となる. 従って, 極めて希薄な懸濁液を大量に濾過する場合などのよう に，懸濁粒子による膜の閉塞があまり大きな問題となら ない場合には, 細孔の粗い膜面側から回分方式で濾過を 行なう方法が有効となる. しかし, 懸濁粒子濃度がある 程度高くなると, 滤過される粒子によって生じる膜閉塞 が無視できなくなり, 極端な場合には, 万液が一滴も出 なくなるほど膜閉塞が進行する．したがって，このよう な場合には, 粒子による膜閉塞が生じにくい膜を採用し， クロスフロー滤過操作や逆洗操作等によって膜面に堆積 した粒子層を取り除いて安定した濾過速度を確保するこ とが重要となるため, 細孔の緻密な膜面側から濾過を行 なう方が有利となる ${ }^{20)}$. 最近では, 膜の両面は細孔が 粗く，その断面の中央に緻密層を有するような膜も市 販され始め21，22），そのひとつである BMM 膜（再生 セルロース膜, 旭化成(株)）はAIDS の原因となる HIV ウイルスを分離するために開発された膜である ${ }^{23)}$. このような膜は, 従来の非対称膜とは異なり, 表裏対称 な構造を有するため, 膜の強度やモジュール加工性に優 れている24).

\section{2 溶融急冷法}

高温では溶剂であるが，低温では非溶剤となるような 溶媒に有機高分子を溶融溶解させ, 膜状に成形した後, 急冷凝固させると, Fig. 2 に示すような網状構造を有す る多孔質膜が得られる。この製法は, 主に, 各種結晶性 高分子(ナイロン, ポリカーボネート, ポリプロピレン, ポリスチレンなど）を素材として多孔質膜を製膜する場 合に利用されている24).

\section{3 延伸 法}

まず，ポリプロピレンやポリエチレンのような結晶性 の高い高分子を溶融した後, 高いドラフト比 (巻取り速 度／吐出速度）で紡糸し, 配向結晶性の高い中空糸を作 る. 次に, 結晶の流動変形の生じない温度において, こ れを延伸すると, 構造的に弱い, 中空系の非晶質部分が 選択的に延伸方向に延ばされて微細孔が形成される.こ 


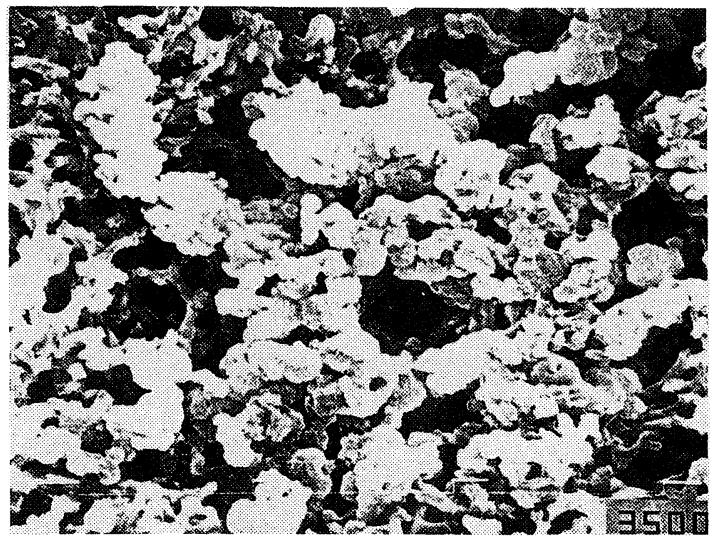

Fig. 2 溶融急冷法で製膜されたナイロン-66 膜の 表面 SEM 写真

(Ultipore 0.8 膜, Pall 社製)

の後, 細孔構造を固定化するための加熱処理を行う場合 もある.

テフロン膜 (Gore-Tex ${ }^{R}$ ) の製法を例によってみる 之, まず, 分子量約 5 万のポリテトラフルオロエチレン (PTFE) にケロシンやナフサを潤滑剤として 15〜25\% 程度混入し, 次に $80^{\circ} \mathrm{C}$ で薄く延ばした後, それらの潤 滑剤を加熱除去する. 次に, 1 軸あるいは 2 軸延伸を行 い, 最後に $327^{\circ} \mathrm{C}$ で焼結する.この方法によれば, 細 孔径 $0.02 \sim 15 \mu \mathrm{m}$, 空隙率 25〜95\%の多孔質膜を得る ことができる25).

\section{4 抽出法 (レプリカ法)}

高分子溶液あるいは分散液中に, 後工程で容易に抽出 できるような添加剤を加え，これを膜状に成形した後, その添加剤を適当な方法で抽出する方法であり, テフロ ン膜の製膜などに利用されている．添加剤としては，各 種塩類, 粒径の均一なシリカや金属の微粉末, 澱粉なよ゙ が採用されている. テフロン膜としては, $0.1 \sim 2 \mu \mathrm{m}$ の 細孔を有するものが工業的に作られている ${ }^{26)}$. 先に相転 換法の項で述べた, $\mathrm{LiCl}$ (添加物) を相転換後に抽出す

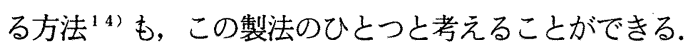

\section{5 電子線照射法}

$10 \mu \mathrm{m}$ 程度の高分子薄膜に電子線（荷電粒子）を照 射することによって, 膜に粒子の軌跡を形成させた後, 溶剤によるエッチング処理を行なうことにより，この軌 跡を広げて微細孔とする製法である. Fig. 3 に示したポ リカーボネート膜 (Nuclepore 膜) はこの方法によっ

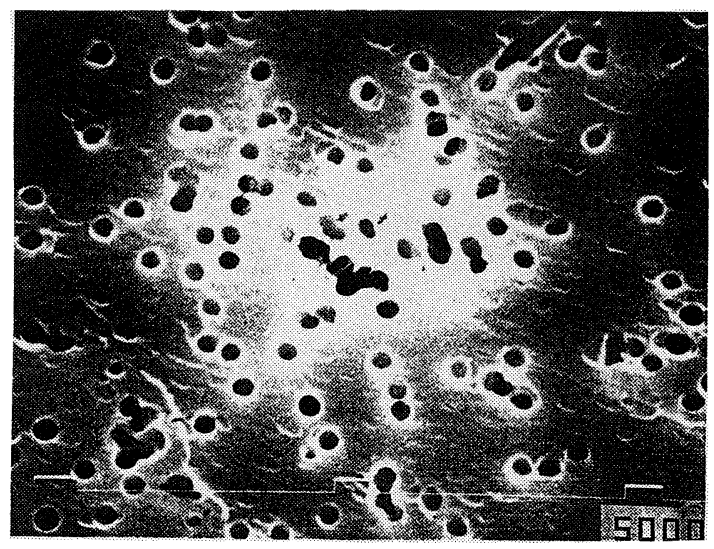

Fig. 3 電子線照射法で製膜されたポリカーボネー 卜膜の表面 SEM 写真

(Nuclepore 0.4 膜, Nucleopore 社製)

て作られている，この製法による膜は，精密濾過に利用 される多孔質膜の中で最も径の均一な円筒型細孔を有す ることが特徴であり, 主に膜表面で微粒子を捕捉するス クリーンタイプのフィルターとして利用されている ${ }^{27)}$. 膜に形成される細孔の径や数は, 電子線照射時間, エッ チングに用いる溶液の種類や濃度, エッチング時間なご によって制御できるが, 最近では，エッチングの際に膜 を隔てた電気伝導度の変化を測定することによって, 膜 に形成される細孔の径をオンラインで計測, 制御する技 術が確立された28).

\section{3. セラミック膜}

\section{1 泥漿成形・焼結法}

まず, 粒径の均一なセラミックス粉体に, 適当な結合 剂之水，あるいは有機溶剂を加えて泥漿を作る. 次に, これを吸水性の型に流し込むと，その型に接した部分だ けが乾燥するので, 内部の泥漿を除くことにより, 成形 がなされる (泥漿鋳込法). 押出し成形法による成形も 可能である. これをセラミックスの融点よりも低い温度 (タンマン温度)で焼結させると, 粒子が互いに融着し, セラミック膜が得られる. 結合剤としては, シリカやマ グネシウムなどが利用されるが, 高温下やアルカリ存在 下におけるセラミック膜の使用の際にこれらが溶出して 劣化の原因となる可能性もあるため，これらの結合剤を ほとんど使用しない高純度セラミック膜なども開発され ている. 管状, あるいは蓮根に似た形状のモノリス型セ ラミック膜は主にこの方法で作製される. 

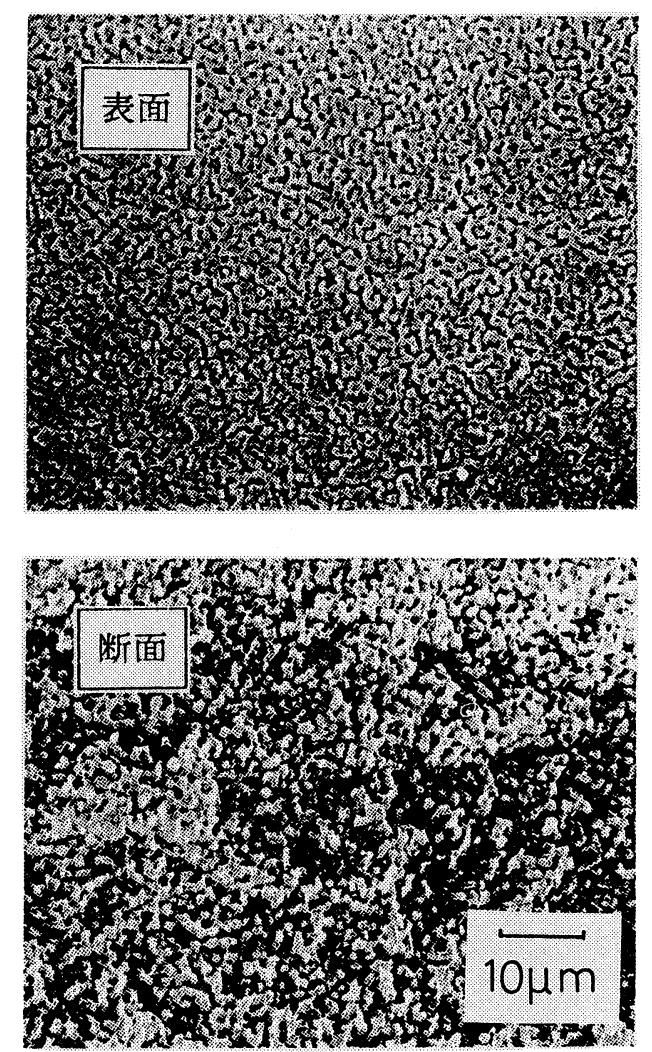

Fig. 4 分相法で製膜されたセラミック膜の SEM 写真 ${ }^{41}$

この製法では，膜に形成される細孔の大きさが，原料 として使用されるセラミックス粉体の粒径に大きく依存 するため, 得られる細孔の大きさは $0.1 〜$ 数 $10 \mu \mathrm{m}$ と比 較的大きい.これよりも小さい細孔を有するセラミック 膜を製膜するには, 多くの場合, この粗い膜を支持材（基 膜）とし, 次に述べるゾルゲル法などによって, その表 面に細かい細孔を有する活性層（実際に分離のなされる 層, 緻密層) を形成ささせる手法が取られる29).

\section{2 ゾルゲル法}

一般に, 微粒子が液体中で沈降せずに分散している場 合に，この微粒子をゾル (コロイド) と呼ぶが, ゾルゲ ル法では，まず，焼成させるとセラミックスになるよう な金属アルコキシドなどを適当な分散媒中にゾル状に懸 濁させる. 次に, セラミック膜の支持材をその中に浸し, ゆっくりと一定の速度で引き上げると, 支持材がゾルで フィルムコーティングされ, それを乾燥させると支持材 表面に均一なゲル層が形成される. 従って, これを焼成
膜 (MEMBRANE), No. 18 Vol. 5 (1993)

させることにより，新たなセラミックスの繳密層を支持 材表面に形成させることができる. 一般に, 1 回のコー ティング操作によって形成される緻密層は非常に薄く, ピンホール（予定外の大きな細孔）が残りやすいため, この操作は繰り返し行われる場合が多い. 膜に形成され る細孔の大きさは，このコーティング回数によって制御 され, 約 1 100 nm の細孔を有するセラミック膜が得 られる。

ゾルゲル法によるセラミック膜の製法としては, ベー

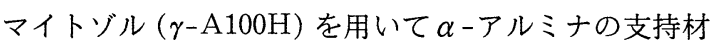
表面に $\gamma$-アルミナ薄層を形成させる方法が数多く報告

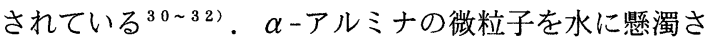
せた液で支持材をフィルムコーティングし, 乾燥, 焼結 させるだけでも, 細孔径 $0.1 \sim 1 \mu \mathrm{m}$ 程度の膜を作るこ とができるが，それよりも細孔の細かい膜は，ベーマイ トゾルを用いなければ得られない33３4).

一方，ゾルゲル法を利用した多孔質シリカガラス膜の 作製も試みられている ${ }^{35)}$. 特に耐アルカリ性を向上さ せる添加物として知られるジルコニアは, 泥漿成形・焼 結法では約 $20 \%$ までしか添加できないが, $\mathrm{Si}$ と Zr の アルコキシドを原料としてゾルゲル法による製膜を行な うと, より高いジルコニア含有量 $(30 \sim 50 \%)$ を有する $\mathrm{ZrO}_{2}-\mathrm{SiO}_{2}$ 系耐アルカリ性多孔質ガラス膜を製膜する ことが可能である ${ }^{35 \text { 37). }}$

\section{3 分相溶出法}

$\mathrm{SiO}_{2}+\mathrm{B}_{2} \mathrm{O}_{3}+\mathrm{Na}_{2} \mathrm{O}$ からなるホウケイ酸ガラスを成 形し, $500 \sim 650^{\circ} \mathrm{C}$ で熱処理すると, $\mathrm{B}_{2} \mathrm{O}_{3}+\mathrm{Na}_{2} \mathrm{O}$ 相と $\mathrm{SiO}_{2}$ 相に分かれる (分相現象). そこで, 酸に可溶な $\mathrm{B}_{2} \mathrm{O}_{3}+\mathrm{Na}_{2} \mathrm{O}$ 相のみを硫酸などを用いた酸処理によっ て溶出すると, 多孔質なシリカガラス層が得られる ${ }^{38)}$. この手法は分相溶出法, あるいは単に分相法と呼ばれて いる.

この製法によって得られるセラミック膜は，一般に， 熱および化学的安定性に優れており, またその細孔径は, 熱処理の温度や, 酸処理に用いる酸の濃度, 処理時間な どによって, 数 $\mathrm{nm}$ から数 $10 \mu \mathrm{m}$ の広い範囲で比較的 容易に制御することができる.したがって,これまでに, 上記組成のホウケイ酸ガラスに微量 (3wt\%) の $\mathrm{Al}_{2} \mathrm{O}_{3}$ を添加した原料による逆浸透膜 ${ }^{39)}$ や気体分離膜 ${ }^{40)}$, $\mathrm{Na}_{2} \mathrm{O}$ の代わりに $\mathrm{CaO}$ を原料に用いた多孔質膜 ${ }^{41}$ な どが作製されている．分相溶出法によって得られたセラ ミック膜の表面および断面の一例を Fig. 4 に示す ${ }^{41)}$. 

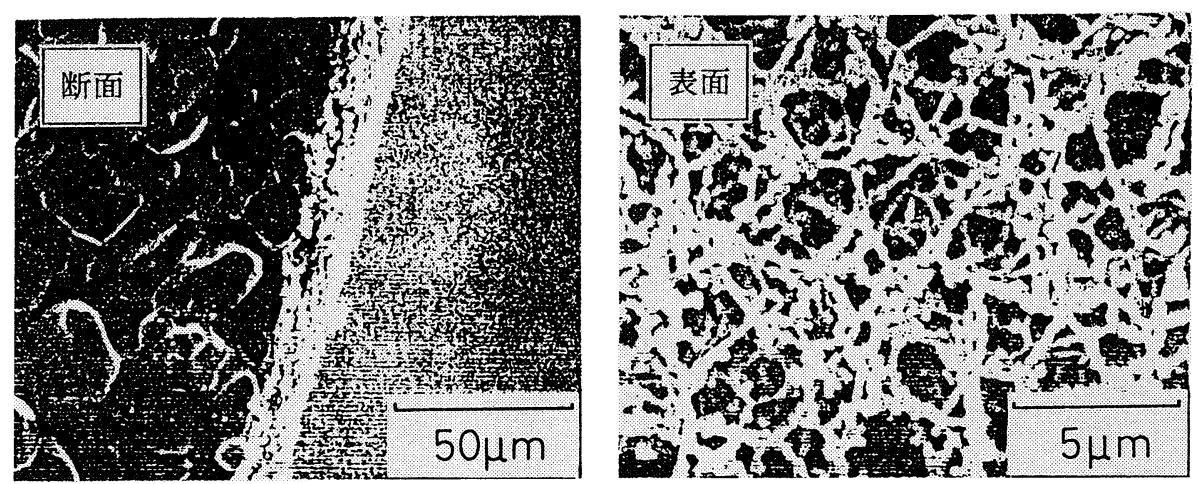

Fig. 5 CVD 法で製膜されたセラミック膜の SEM 写真 ${ }^{42)}$

\section{4 CVD 法}

CVD 法は, 気体原料から化学反応を経て薄膜や微粒 子などの固体材料を合成するプロセスであるが，最近に なって，気相中で合成した超微粒子を強制荷電し，それ を直流電界によってセラミック膜の支持体表面に沈着さ せ，そのまま焼結させて緻密層を得るという新しいセラ ミック膜の製法が開発された ${ }^{42.43)}$.この製法によれば, 支持膜表面に堆積したセラミックスの超微粒子が, 誘電 分極によってパールチェーン状につながり，そのまま焼 結するため, $0.1 \mu \mathrm{m}$ から数 $\mu \mathrm{m}$ 程度の極めて均一な径 の細孔が得られ，かつ，高い空隙率を有する活性層（緻 密層）が支持材表面に形成される. 得られたセラミック 膜の表面および断面の一例を Fig. 5 に示す ${ }^{42)}$.

この製法において，形成される細孔の大きさを支配し ている因子は, 最初の気相反応によって得られる超微粒 子の粒径であるが，これは気相反応の原料となる反応力゙ スの濃度によって制御できるため, 細孔径の制御も比較 的容易である.

\section{5 溶出処理によるムライト質多孔体の作製}

$\mathrm{Al}_{2} \mathrm{O}_{3}$ と $\mathrm{SiO}_{2}$ を主成分とするセラミックスの焼成体 には, 発達したムライト $\left(3 \mathrm{Al}_{2} \mathrm{O}_{3} \cdot 2 \mathrm{SiO}_{2}\right)$ の結晶が形 成される.そこで, そのマトリックスを混酸 $(\mathrm{HF}+\mathrm{HCl}$ $\left.+\mathrm{H}_{2} \mathrm{SO}_{4}+\mathrm{H}_{2} \mathrm{O}\right)$ によって溶出させ，ムライト質のみを 残すことにより，多孔質体を得るのが本製法である。こ の製法では，原料となる $\mathrm{Al}_{2} \mathrm{O}_{3}+\mathrm{SiO}_{2}$ に添加する第 3 成分によって, Fig. 6 に示したような異なる細孔構造を 有するセラミック膜が得られる ${ }^{44)}$ ．その細孔径は, 第 3 成分として $\mathrm{CaO}$ を添加した場合に約 $3 \mu \mathrm{m}$, その他の 成分を添加した場合にはサブミクロンの範囲である.

\section{4. 金 属 膜}

金属膜は，七ラミック膜と同様に，耐熱性（高温およ び低温）に優れているものの, 高温側の限界耐熱温度は セラミック膜の場合よりもやや低い $\left(\right.$ 約 $\left.500^{\circ} \mathrm{C}\right)$.しかし, 機械的強度はかなり高く, 特に耐衝撃性に関してはセラ ミック膜よりもはるかに優れている，また，素材となる 金属は成形加工性に優れているため，すでに構造の異な る種々の金属膜が市販されている，金属膜は一般に，酸 化されにくいステンレス鋼の粉末，金網，長繊維，短緎 維などを膜状に成形し, 無酸素雾囲気中で焼結する方法 によって製膜される ${ }^{45 \sim 47)}$. 膜の空隙率は原料となる ステンレス鋼の形状や大きさなどによってかなり自由に 制御することが可能であるが，高い空隙率を有する金属 膜を製膜する場合には，金属薄板に無数の孔を打ちぬい たパンチングメタルや適当な金網などにより，その片側 あるいは両側を補強する必要がある，金属素材としては ステンレス鋼の他に，真鍮やニッケルなどの合金なども 用いられる ${ }^{24)}$.

\section{5.おわりに}

精密濾過に用いられる多孔質膜の製法について過去に 報告された論文等を中心に整理・概説してきたが，一般 に，有機高分子膜および金属膜の場合には，すでにその ほとんどの製法が実用化され，数多くの多孔質膜が商品 化されているのに対して，セラミック膜の場合には，依 然として研究段階に留まっている製法が多い。これは, 素材（セラミックス）の性質上, 焼成や高温処理を必要 とすることや, 得られる膜が柔軟性に欠け, 特に耐衝撃 性に乏しいために扱いが容易でないこと，さらに他の素 

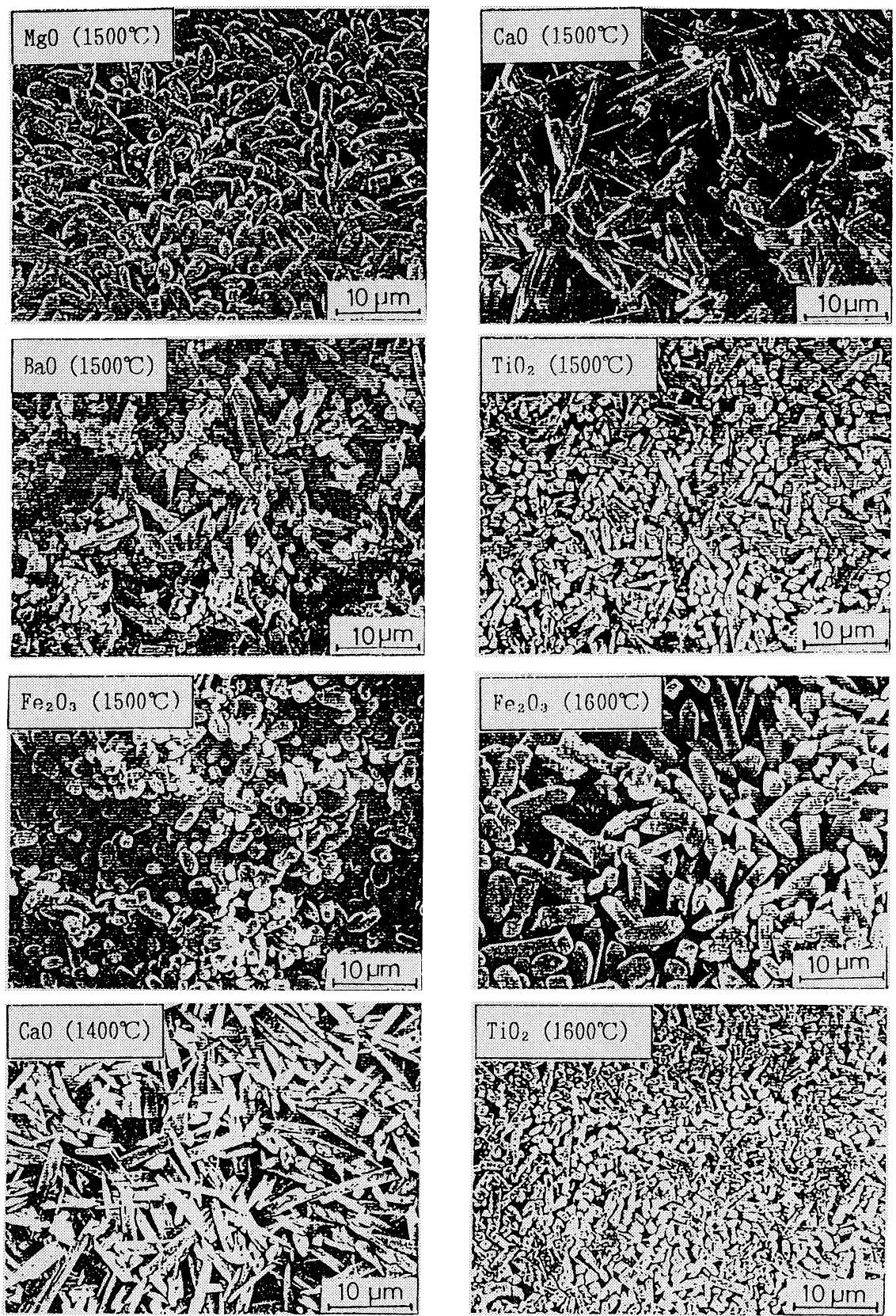

Fig. 6 第 3 成分と焼成温度(図中)が溶出処理によって得られるムライト質多孔質体の構造に及ぼす影響 (表面 SEM 写真)

材(有機高分子，金属)の場合よりも膜が高価になること などが原因となって，大量生産に結びっけにくいことが その主な原因であろうと推測される。しかし，セラミッ ク膜には, 耐熱性, 耐薬品・溶剤性, 寸法安定性, 機械的 強度（耐圧性）等に優れるといった数多くの長所がある
ため, 従来の多孔質膜では使用に絶えられないような新 たな工業分野に適用されていくことが期待されており， その製法は大量生産，低価格化に向けて，今後，さらに 発展していくものと思われる. 


\section{文献}

1）殿岡康彦, 井上一郎 : 理化学研究報告, 61 (4), 161 (1985)

2) 西村民男 : 防菌防, 17 (1), 23 (1989)

3) Manjikian, S. and M. I. Foley : OSW R \& DP Rept., No. 612 (1970)

4）松田正治, 神沢千代志，小林力夫 : 膜, 12 (1), 49 (1987)

5) Schwarz, K. R and H. G. Hicke : J. Membr. Sci., 34, 283 (1987)

6) Yunlan, G., S. Mingren and H. Jiajun : Desalination, 62, 173 (1987)

7) Bodzek, M. and J. Bohdziewicz : J. Membr. Sci., 60, 25 (1991)

8) Chen, L. and T. Young : J. Membr. Sci., 59, 15 (1991)

9) Bargeman, D., E. Vugteveen, J. Hennepe, J. Van't Hof and C. A. Smolders : Synth. Polym. Membr., Prc. Microsymp. Macromol., 29 th, 637 (1987)

10) Lafreniere, L. Y., F. D. F. Talbot, T. Matsuura and S. Sourirajan : Ind. Eng. Chem. Res., 26 (11), 2385 (1987)

11) Bodzek, M. and J. Bohdziewicz : J. Membr. Sci., 60 (1), 25 (1991)

12) Schwarz, H.H. and K. Richau : Synth. Polym. Membr., Prc. Microsymp. Macromol., 29 th, 591 (1987)

13) Schwarz. H. H., K. Richau and H. G. Hicke : J. Membr. Sci., 34 (3), 283 (1987)

14) Bottino, A., G. Capannelli, S. Munari and A. Turturro : Desalination, 68 (2-3), 167 (1988)

15) Zhenkun, Z., Z. Huanxin and C. Ruiying : Desalination, 62, 165 (1987)

16) K. H. Maier and W. Grassmann:U. S. Pat. 3, 129, 159 (1961)

17）富士写真フィルム（株）: 特開, 昭 50-122565 (1975)

18) S. Lovell and J. Bush : U. S. Pat. 2, 783, 894 (1955)

19）住友電気工業(株)：特開，昭 49-118761 (1974)

20) 川勝孝博, 中尾真一, 木村尚史 : 化学工学会大 57 年会要旨集, B117 (1992)

21）大野清一：防菌防, 11, p. 588 (1983)

22) 大谷純也, 佐々木純 : 化学工学協会第 54 年会要旨 集, p. 656 (1989)
23) 真鍋征一: Boundary, 4, 63 (1988)

24) 松本幹治, 平田 繁: “最近の化学工学 41 膜分離 工学一その現状と工業的応用一”，77, 化学工業社 (1989)

25）大矢晴彦，丹羽雅裕：“高機能分離膜” , p. 3, 38, 39 , 共立出版 (1988)

26)メリッシュ, S. F.: 特公, 昭 46-25267 (1971)

27）大矢晴彦：“膜利用技術ハンドブック”，P. 715, 幸 書房 (1978)

28) Mehla, P. S., S. K. Chakarvarti and N. Singh: Nucl. Tracks Radiat. Meas., 15 (1-4), 305 (1988)

29) 清水康利 : 膜, 15 (4), 179 (1990)

30) B.E. Yoldas : Ceramic Bulletin, 54, 286 (1975)

31）鈴木文男, 小野里健二, 柳沼淳子, 黒川洋一：高分 子論文集, 43 (11), 767 (1986)

32) Leenaars, A. F. M. and A. J. Burggraaf : J. Colloid Interface Sci., 105 (1), 27 (1985)

33) Terpstra, R. A., B. C. Bonekamp, H. M. van Veen, A. J. G. Engel, R. de Rooy and H. J. Veringa : Sci. Ceramics, 14, 557 (1988)

34) Terpstra, R. A., B. C. Bonekamp and H. J. Veringa : Desalination, 70, 395 (1988)

35) MOL 編集部: MOL, (1), 24 (1987)

36) Yazawa, T., H. Tanaka, H. Nakamichi and T. Yokoyama : J. Membr. Sci., 60, 307 (1991)

37) 野上正行 : 窒素協会誌, 93 (4), 195 (1985)

38) Schnabel, R. and W. Vaulont : Desalination, 24, 249 (1978)

39）矢沢哲夫, 田中博史, 江口清久, 山黒隆夫 : 日本化 学会誌, (5), 866 (1985)

40) 矢沢哲夫, 田中博史, 江口清久 : 日本化学会誌, (2), 201 (1986)

41）中島忠夫, 清水正高 : 化学工学論文集, 15 (3), 645 (1989)

42) 山本英夫：ケミカル・エンジニアリング, (12), 985 (1990)

43) Lin, Y. S. and A. J. Burggraaf : Chem. Eng. Sci., 46 (12), 3067 (1991)

44）阿部久雄, 関秀哉, 福永昭夫, 江頭誠 : 日本セラミッ クス協会学術論文誌, $97(6), 604$ (1989)

45) 西村正人: $M O L, 24,21$ (1986)

46）松永有志夫 : “ニューメンブレンテクノロジーシン ポジウム 89'”, p. 5-1-1, 日本能率協会 (1989)

47) 水木正光 : 同上, p. 5-2-1 (1989)

（受付 1993 年 7 月 5 日） 